\title{
Developing Android-Based Historytoon Media in History Learning
}

\author{
Septia Rahandinasari \\ Graduate School \\ Universitas Negeri Yogyakarta \\ Yogyakarta, Indonesia \\ rahandina28@gmail.com
}

\begin{abstract}
Nowadays, the advancement of information and communication technology is growing rapidly, especially in the field of education, hence it is necessary to develop a learning media that is based on information and communication technology. The development of instructional media must be in accordance with the learning objectives. Besides, the learning media should be able to make students interested to learn independently as directed by the teacher. The aim of this research is to develop a history learning media in the form of online comic reading services (named Historytoon). The researcher tested the Historytoon application by conducting a formative evaluation involving students from a senior high school in Yogyakarta. Based on the testing on the learning media, a decent history learning media can be produced and the media itself can improve the understanding on the materials of the Indonesian National Movement History in the eleventh grade of senior high school.
\end{abstract}

Keywords- Historytoon media, Android, History Learning

\section{INTRODUCTION}

Contemporary education is currently growing rapidly with the advent of technology and information. Modern people are very fond of using mobile computers, hence various applications have been designed to facilitate the human life. One of the applications favored by students is the comic reading service with mobile computer application media [12]. The online comic reading service application that can be used as a means of learning history is Historytoon. The Historytoon application can be used for history learning.

The Historytoon media is basically an application created by a software and can be used in Smartphone devices. The use of this media can facilitate the teaching and learning process, even more to achieve the expected learning goals. The concept of comics is generally favored by students because it looks fresh and unique, and it uses digital media, while it is created using manual techniques [1]. Historical comic images that are displayed are simple, easy to understand, and interesting enough. Nowadays, there is a rapid development of technology, it explains why comics can be accessed online. The function of comics is also changing, comics are no longer merely children's literature, but they also provide knowledge and help students to relieve stress and boredom.

\author{
Djoko Suryo \\ Graduate School \\ Gajah Mada University \\ Yogyakarta Indonesia \\ djoko98@yahoo.com
}

The Historytoon media is expected to be able to change the image that has been inherent in the history learning. This image is a classic problem in the history learning, namely in the form of lessons that force students to memorize a lot, contain a lot of writing, are less interesting, and boring [19].

History learning is not only judged from the image that has been attached to it. The image is not completely correct nor completely wrong. Therefore, a study in history learning is needed so that it can help teachers and students towards a better history learning.

Based on the description of the problem, the researcher tried to help teachers in high schools through the development of learning media in the form of Historytoon applications as an effort to improve understanding of the historical material of the Indonesian National Movement.

\section{RESEARCH METHOD}

This research's development model uses the research and development methods commonly known as Research and Development (R\&D). Research and Development ( $R$ \& D) according to Sugiyono is a research method that is used to produce certain products and test the effectiveness of these products [21]. Research can produce quality products if the research based on a need's analysis. It can be said that a product works well in the community if the research has been tested to find the effectiveness of the product. The product produced in this study is the Historytoon media and is in the form of an Android application. The Historytoon media development uses the ADDIE model. This model consists of five main phases or stages, namely; (A)nalysis, (D)esign, (D)evelopment, (I)mplementation, and (E)valuation [18].

\section{A. Needs Analysis}

Need analysis was done to determine the product objectives to be developed.

\section{B. Media Design}

At this stage of learning design development, the learning syllabus as the basis for developing Historytoon media was developed.

\section{Media Development}

At this stage, the Smartphone application was used because it presents the materials in the form of comic images that can be accessed using Smartphones and tablets with the Android OS operating system. 


\section{Implementation,}

The implementation stage was done by formative evaluation consisted of validation, trial, and product revision.

\section{E. Evaluation,}

Evaluation was carried out to determine the effectiveness or function of the product or the final program in improving the quality of learning in the form of increasing achievement of learning outcomes.

Data obtained through trial activities are clarified in two parts, namely qualitative data and quantitative data. In this research, qualitative data took the form of criticism and suggestions from material experts, media experts, history teachers, and students. In addition, qualitative data was also obtained based on observations. These data were then collected and abstracted to improve Historytoon media products on history learning. Quantitative data in this study were the scores on each instrument item filled by material experts, media experts, and trial subjects. Other quantitative data were in the form of pre-test and posttest data on the implementation of the test in the field. The media eligibility criteria used was tables from Sukardjo [22], as described as follows: $X>4.21$ means very good; $3.40<\mathrm{X} \leq 4.21$ means good; $2.60<\mathrm{X} \leq 3.40$ means good enough; $1.79<\mathrm{X} \leq 2.60$ means poor; and $\mathrm{X} \leq 1.79$ means very poor.

\section{RESULTS AND DISCUSSIONS}

\section{A. The Historytoon Media Development Results}

TABLE I. THE INDIVIDUAL TRIAL RESULTS DATA

\begin{tabular}{lll}
\hline \multicolumn{1}{c}{$\begin{array}{c}\text { Margin cat } \\
\text { Assessment Aspect }\end{array}$} & Average Score & $\begin{array}{l}\text { Percentage } \\
(\mathbf{\%})\end{array}$ \\
\hline Learning & 4.16 & 24.63 \\
Content/Material & 4.33 & 25.64 \\
Display & 4.07 & 24.09 \\
Technical & 4.33 & 25.64 \\
Total Scores & 16.89 & 100 \\
Mean Score & 4.22 & \\
Category & \multicolumn{2}{c}{ Very Good } \\
\hline
\end{tabular}

The assessment results of overall aspects in the small group trial show that the learning aspect's score is 4.07 (good category), content/material aspect's score is 4.16 (good category), media (appearance) aspect's score is 4.04 (good category), and media (technical) aspect's score is 4.18 (good category).

TABLE II. THE SMALL GROUP TRIAL RESULTS DATA

\begin{tabular}{lll}
\hline \multicolumn{1}{c}{$\begin{array}{c}\text { Margin cat } \\
\text { Assessment Aspect }\end{array}$} & \multicolumn{1}{c}{ Average Score } & Percentage (\%) \\
\hline Learning & 4.07 & 24.74 \\
Content/Material & 4.16 & 25.29 \\
Display & 4.04 & 24.56 \\
Technical & 4.18 & 25.41 \\
Total Scores & 16.45 & 100 \\
Mean Score & $4.11 \quad$ Good \\
Category & \multicolumn{2}{c}{} \\
\hline
\end{tabular}

Historytoon's media products were packaged in the form of Android-based Smartphone applications. At the stage of product development, identification and collection of historical learning materials were carried out. In this product, the researcher took the Indonesian National Movement materials. The researcher then looked for data and sources from various written sources and then summarized the materials obtained from the source. After the materials collection process was thought to be enough, the researcher then designed the appearance of the application and began to make comic pictures. Next, the stages of application design programming were conducted by making UI design (User Interface), making diagram class design, and making pseudocode to create an application that is ready to run on a Smartphone or tablet. Making comic drawings were done with the stages of making comic themes, creating a synopsis of comic stories, creating a script, and lastly translating in the form of images. After that, the editing and review process were carried out to make changes to images, colors, and texts. Comic pictures that have been repaired will be uploaded into the application in accordance with the sub-chapter / episode.

Figure 1 shows the initial appearance of the Historytoon application along with its supporting features, such as: 1) application profile; 2) orientation; 3) quiz; and 4) competency standards.

Figure 2 shows the episode display on the Historytoon application in the form of historical materials of the Indonesian National Movement, with the episode titles: 1) Introduction, 2) Background; 3) Resistance to the PNI Radical Organization; 4) The Youth Pledge and 5) Towards Indonesia in Volksraad.

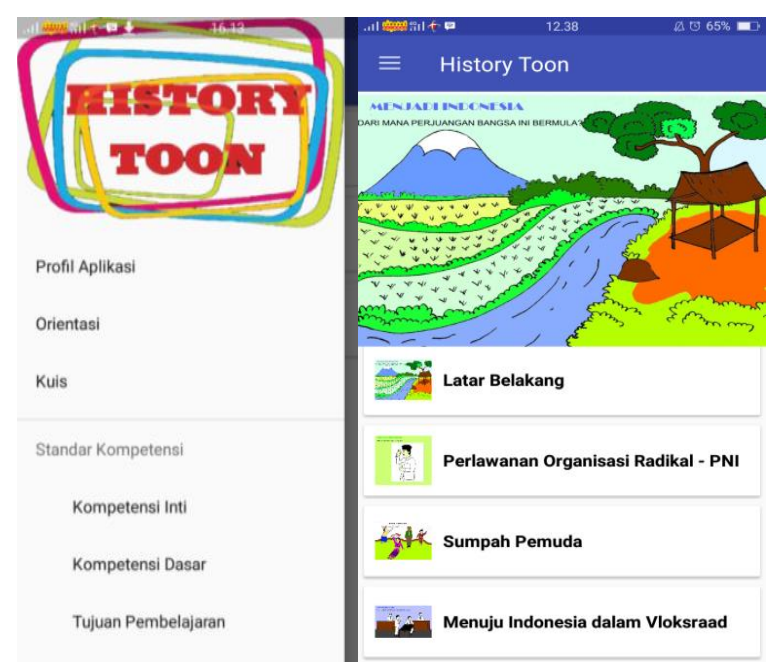

Fig 1. The Initial Appearance of The Historytoon Application and The Episode Display on The Historytoon Application

\section{B. The Historytoon Media Test Results (Formative Evaluation)}

The Historytoon's media development for history learning has been developed. The feasibility test for the Historytoon media has been developed through several stages, namely validation by material experts, validation by media experts, teacher testing as users, 
individual trials, small group trials and finally field trials. The effectiveness test was done by conducting summative evaluation using two classes.

The results of the assessment from the material experts towards the aspects of learning and content of the materials show that the mean score is 4.00 (good category). The results of the assessment from the media experts in terms of appearance and technical aspects show that the mean score is 4.00 (good category). The results of the assessment from the teacher as the user in terms of learning aspects and content of the materials show that the mean score is 4.18 (good category).

The assessment results of overall aspects in the individual trial show that the learning aspect's score is 4.16 (good category), content/material aspect's score is 4.33 (very good category), media (appearance) aspect's score is 4.07 (good category), and media (technical) aspect's score is 4.33 (very good category).

The assessment results of overall aspects in the field trial show that the that the learning aspect's score is 3.86 (good category), content/material aspect's score is 3.94 (good category), media (appearance) aspect's score is 3.89 (good category), and media (technical) aspect's score is 3.95 (good category).

After considering the assessments of the aspects above, it can be concluded that the developed media is categorized as good.

\section{Media Effectiveness Test Results}

In the summative evaluation activities that have been carried out, the class that uses the Historytoon media has an effect size of 9.84, while the class that uses the textbooks and media presentation of Ms. PowerPoint has an effect size of 4.57. Hence, the learning outcomes in the class that uses Historytoon media are better than the class that uses textbooks and the media presentation of Ms. PowerPoint, with the difference between classes of 5.27 points. Based on these results, it can be said that the Historytoon media that was developed effectively can improve the students' understanding of the materials of the historical Indonesian National Movement.

\begin{tabular}{|c|c|c|c|c|}
\hline \multirow{2}{*}{ Variable } & \multicolumn{2}{|c|}{$\begin{array}{l}\text { Class XI Social } \\
\text { Science } 1\end{array}$} & \multicolumn{2}{|c|}{$\begin{array}{l}\text { Class XI Social } \\
\text { Science } 2\end{array}$} \\
\hline & Pretest & Posttest & Pretest & Posttest \\
\hline $\begin{array}{l}\text { The Highest } \\
\text { Score }\end{array}$ & 86 & 93 & 80 & 83 \\
\hline $\begin{array}{l}\text { The Lowest } \\
\text { Score }\end{array}$ & 63 & 73 & 50 & 50 \\
\hline Average Score & 74.20 & 84.04 & 70.08 & 74.65 \\
\hline $\begin{array}{l}\text { Effect Size } \\
\text { Interclass Effect }\end{array}$ & 9.84 & & 4.57 & \\
\hline Size Difference & 5.27 & & & \\
\hline
\end{tabular}

The Historytoon media development for history learning has been finished. The feasibility test for the Historytoon media has been developed through several stages, namely validation by material experts, validation by media experts, teacher testing as users, individual trial, small group trial and lastly field trial. The effectiveness test was done by conducting a summative evaluation using two classes. After considering the assessment of the results of the trials, it can be concluded that the media developed is categorized as good and very good so that it can be said that the media is suitable for history learning.

Based on the students' responses to the Historytoon media that are being developed, the advantages of Historytoon's media products in history learning is that the media is able to present history materials in the form of graphic images that help students to understand the materials of history subject more interestingly. The interest of the students in the learning media is one indicator that supports the increasing understanding of the history materials of the Indonesian National Movement relating to the learning processes and outcomes. Appearance elements that are considered interesting and good in Historytoon media include the media design, media application appearance, comic images presentation, story selection concept, color selection, and background.

\section{CONCLUSION}

The results show that the product of Historytoon TABLE III. THE INDIVIDUAL TRIAL RESULTS DATA

\begin{tabular}{lll}
\hline Assessment Aspect & Average Score & Percentage (\%) \\
\hline Learning & 3.86 & 24.69 \\
Content/Material & 3.94 & 25.19 \\
Display & 3.89 & 24.87 \\
Technical & 3.95 & 25.25 \\
Total Scores & 15.64 & 100 \\
Mean Score & $3.91 \quad$ Good \\
Category & & \\
\end{tabular}

media in the history learning can improve the understanding of the materials of Indonesian Nation Movement.

\section{ACKNOWLEDGMENT}

Acknowledgment are convoyed to: (1) Rector and academic community of Universitas Negeri Yogyakarta who have provided facilities, moral support, and study permission to the researcher to continue the study of Master level: (2) Dr. Dyah Kumalasari, M.Pd and Prof. Herman Dwi Surjono, Drs., M.Sc., MT., Ph.D. who has reviewed and validated the instrument of this research: (3) Headmaster and High School Teachers in Yogyakarta who have been willing to take the time to complete the instrument in this research.

\section{REFERENCE}

[1] Amanda, N, Waluyanto, dan Zacky. Perancangan Komik Digital Menggunakan Aplikasi LINE Webtoon Tentang Pola Makan Sesuai Golongan Darah untuk Remaja. Jurnal DKV Adiwarna, 1: 1, 2016.

[2] Ardiansyah, F. Pengenalan Dasar Android Progaming. Depok: Biraynara, 2011.

[3] Arsyad, A. Media Pembelajaran. Jakarta: Rajawali Press, 2009. 
[4] Borg, W. R. and Gall, M. D. Education Research an Introduction, Seventh Editions. United States of America: University of Oregon, 2003.

[5] BSNP. Permendiknas RI No. 22 Tahun 2006 tentang Standar Kompetensi Lulusan Pendidikan Dasar dan Menengah. Jakarta, BSNP, 2016

[6] Burd, B. Android Application Development: All in One for Dummies. New Jersey: Wiley Publishing, 2012

[7] Choi, Y. S. and Yu, S. Y. The Advertising Effect of PPL within Webtoon: Focusing on the Components of Engagement. Indian Journal of Science and Technology, 9(26): 2016, pp. 1-2

[8] Darmawan, D. Teknologi Pembelajaran. Bandung: Remaja Rosdakarya, 2013.

[9] Hamid, A. R. Pembelajaran Sejarah. Yogyakarta: Ombak, 2014.

[10] Hamid, A. R. \& Madjid, M. S. Pengantar Ilmu Sejarah. Yogyakarta: Ombak, 2011.

[11] Harckbarth. The Educational Technology Handbook. New Jersey: Educational Technology Publications, Inc., 1996.

[12] Harmoko, D. B. \& Sumbawati, M. S. Pengembangan Mobile Webtoon Pada Mata Kuliah Pemrograman Game di Universitas Negeri Surabaya. Jurnal IT-EDU, 2(1): 2017, pp. 102.

[13] Haydn, T. History in Schools and The Problem of "The Nation". Journal Education Sciences (Educ.Sci), 2: 2012, pp. 277.

[14] Kim, K. Design and Implementation of IVEF Protocol Using Wireless Communication on Android Mobile Platform. Jurnal Computer Applications for Security, Control System Engineering, 339: 2012, pp. 96.

[15] Larsen, J. E. Knowledge, Politics, and the History of Education. Berlin: LIT Publishing, 2012

[16] Matos, V. and Grasser, R. Building Applications for the Android OS Mobile Platform: A Primer and Course Materials. Journal of Computing Sciences in College, 26(1): 2010, pp.

[17] Prastya, A. Strategi Pemilihan Media Pembelajaran Bagi Seorang Guru. Prosiding Temu Ilmiah Nasional Guru VII, di Universitas Terbuka Convention Center Tahun 2016, 300.

[18] Pribadi, B. A. Model Desain Sistem Pembelajaran. Jakarta: Dian Rakyat, 2009.

[19] Sayono, J. Pembelajaran Sejarah di Sekolah: Dari Pragmatis ke Idealis. Jurnal Sejarah dan Budaya, 7(1): 2013, pp. 9.

[20] Setyosari, P. Pemilihan dan Penggunaan Media Pembelajaran. Naskah Pendidikan dan Latihan Profesi Guru Universitas Negeri Malang. Malang: Panitia Sertifikasi Guru Rayon 15 Universitas Negeri Malang, 2008.

[21] Sugiyono. Metode Penelitian Pendidikan Pendekatan Kuantitatif, Kualitatif dan R\&D. Bandung: Alfabeta, 2016.

[22] Sukardjo. Evaluasi Pembelajaran Bidang Studi. Yogyakarta: Universitas Negeri Yogyakarta, 2010

[23] Yoon, K. H. Features of Korean Webtoons through the Statistical Analysis. Journal Korean Society of Cartoon and Animation Studies, 2015 
